DOI

\title{
ВПЛИВ КСЕНОБІОТИКІВ У ПОВІТРІ НА ПЕРЕБІГ АНГІОПАТІЇ У ЩУРІВ З МОДЕЛЛЮ СИСТЕМНОГО АУТОІМУННОГО РЕВМАТИЧНОГО ЗАХВОРЮВАННЯ
}

\author{
○Є. Д. Єгудіна', Г. С. Такташов², В. Я. Мікукстс², О. В. Синяченко², В. І. Суярко² \\ 1 ДЗ «Дніпропетровська медична академія МОз України», \\ ${ }^{2}$ Донецький національний медичний університет (м. Лиман)
}

РЕЗЮМЕ. Системні аутоімунні ревматичні захворювання (САРЗ) пов'язані з несприятливими факторами навколишнього середовища, які визначають темпи прогресування і виживання хворих. Забруднення атмосфери полютантами сприяє збільшенню в таких регіонах поширеності цих хвороб.

Мета дослідження - оцінити вплив ксенобіотиків у повітрі на характер морфологічних змін судин легень, серця і нирок у тварин з моделлю САРЗ.

Матеріали та методи. Експеримент проводили на безпородних щурах, яких поділили на три групи: в першу увійшли тварини з моделлю ССД, які перебували щодня по п'ять годин у несприятливому атмосферному середовищі (аміак+бензол+формалін), другу склали тварини з моделлю захворювання, які знаходилися в звичайних екологічних умовах, а в третю увійшли інтактні щури, яких поміщали в середовище з високим вмістом у повітрі ксенобіотиків, як і представників першої групи. Гістологічні зрізи тканин серця, легень і нирок фарбували гематоксиліном-еозином, альціановим синім і за ван-Гізон, ставили PAS-реакцію.

Результати. Зміни з боку легень, серця і нирок виявлені у всіх тварин з експериментальним САРЗ і, відповідно, у 47 \% , 47 \% і 40 \% спостережень інтактних щурів, які перебувають в несприятливому середовищі 3 забрудненням повітря ксенобіотиками. Негативна екологічна ситуація підвищувала частоту таких морфологічних ознак захворювання як проліферація ендотелію судин серця на 68 \% і ниркових артеріол на 52 \%, до того ж, існували прямі кореляційні зв'язки між ступенем ангіопатії в окремих органах, що залежало від характеру моделювання патологічного процесу і доводило, що забруднення атмосфери $\epsilon$ фактором ризику захворювання у людей. Безпосередньо з моделлю САРЗ був пов'язаний вплив склерозу легеневих судин на розвиток бронхосклерозу, периваскулярної інфільтрації м'яза серця, тоді як забруднення повітря ксенобіотиками визначало залежність ступеня клітинної інфільтрації альвеолярних перегородок від периваскулярною легеневої інфільтрації, розвиток гіпертрофії кардіоміоцитів - від проліферації ендотелію судин серця, збільшення мезангіального матриксу нирок - від проліферації ендотелію клубочковох капілярів.

Висновок. Забруднення атмосфери ксенобіотиками слід розглядати як негативний фактор щодо розвитку і подальшого перебігу САРЗ у людей, а в патогенезі його провідне значення має ангіопатія.

КлючовІ слОВА: системне аутоімунне ревматичне захворювання; експеримент; судини; повітря; ксенобіотики.

Вступ. Поширеність системних аутоімунних ревматичних захворювань (САРЗ) повсюди зроста $\epsilon[1,2]$, а спільною ознакою для них вважають наявність у крові різних аутоантитіл та зміни з боку судин серця, легень і нирок [3-6]. Патогенез такої ангіопатії (васкулопатії) залишається вивченим недостатньо [7], хоча саме тяжкість судинних ушкоджень визначає прогноз цих хвороб $[8,9]$. Збільшити інформацію про роль судинної патології в патогенетичних побудовах уражень серця, легень і нирок при САРЗ можуть експерименти на тваринах, але результати таких досліджень залишаються ще дуже суперечливими та вимагають подальшого вирішення [10-12]. Слід зазначити, що розвиток САРЗ у людей пов'язаний з несприятливими чинниками довкілля [13-16], які визначають темпи прогресування і виживаність хворих [17].

Мета дослідження - оцінити вплив ксенобіотиків у повітрі на характер морфологічних змін судин легень, серця й нирок у тварин з моделлю CAP3.
Матеріал і методи дослідження. Експеримент проведено на нелінійних щурах з середньою масою близько 250 г за методикою, запропонованою раніше для моделювання САРЗ [10, 18]. У роботі було задіяно 60 тварин (40 самиць $\mathrm{i}$ 20 самців), яких поділили на 3 групи: в 1, основну, увійшли 25 особин з моделлю САРЗ, які перебували щодня впродовж 5 годин у несприятливому атмосферному середовищі, 2 групу (контрольну) склали 20 тварин з моделлю захворювання, які містилися в звичайних екологічних умовах, а до 3 групи (ще одна контрольна) увійшли 15 інтактних щурів, яких поміщали в середовище з високим вмістом в повітрі ксенобіотиків, як і представників 1 групи. Тварини 1 і 3 груп вдихали повітря 3 концентрацією $0,6 \pi / \mathrm{M}^{3} 1 \%$ розчину аміаку, $1,3 \pi / \mathrm{M}^{3}$ $50 \%$ розчину бензолу у бензині і 2,5 л/ $/ \mathrm{M}^{3} 100 \%$ розчину формаліну. До кінця експерименту живими залишилися 19 особин основної групи (76,0\% від числа використаних тварин), 17 (85,0 \%) - 2 і всі 15 - 3. Щурів виводили з експерименту на тлі 
Огляди літератури, оригінальні дослідження, погляд на проблему нембуталового внутрішньочеревного наркозу (50 мг/кг). Гістологічні зрізи препаратів легень, серця й нирок забарвлювали гематоксиліном-еозином, альціановим синім (на глікопротеїди) і за ван-Гізон (колагенові та еластичні волокна), ставили PAS-реакцію. Підраховували інтегральний середній показник пошкоджень (СПП) [1012]. Експеримент був схвалений етичним комітетом Донецького національного медичного університету.

Статистичну обробку отриманих результатів досліджень проведено за допомогою комп'ютерного варіаційного, кореляційного, непараметричного, одно- (ANOVA) й багатофакторного (ANOVA/MANOVA) дисперсійного аналізу (програми "Microsoft Excel» i "Statistica-Stat-Soft», США). Оцінювали середні значення, їх стандартні відхилення та помилки, параметричні коефіцієнти кореляції Пірсона і непараметричні Кендалла, критерії дисперсії Брауна-Форсайта й Уїлкоксона-Рао, відмінності Стьюдента та МакнемараФішера, а також вірогідність статистичних показників.

Результати й обговорення. Зміни з боку легень, серця і нирок виявлено відповідно у 84,3 \%, 84,3 \% і 82,4 \% від числа щурів (у всіх тварин 1 і 2 груп, відповідно в 46,7 \%, 46,7 \% і 40,0 \% спостережень 3 групи). Таким чином, несприятлива атмосфера викликає ураження цих органів у кожного другого-третього інтактного щура. Екологічна ситуація з високою концентрацією в повітрі ксенобіотиків посилює морфологічні ознаки експериментального САР3, а тому забруднення атмосфери $\epsilon$ чинником ризику перебігу захворювання у людей.

Сумарний (інтегральний) СПП внутрішніх ор-

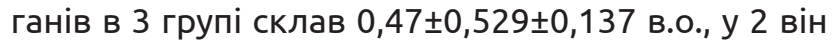

був більшим в 3,2 раза, а в 1 виявився достовірно більшим, порівняно з 2 групою, на 19 \%. Як свідчать результати виконаного багатофакторного дисперсійного аналізу Уїлкоксона-Рао, характер експериментальної моделі впливає на інтегральні морфологічні ознаки уражень легень та серця. Як свідчить однофакторний аналіз Брауна-Форсайта, існує залежність таких окремих показників як проліферація ендотелію судин легень і серця, периваскулярна інфільтрація й склероз у міокарді.

Склероз/гіаліноз стінки легеневих судин встановлено в 84,3 \% випадків, периваскулярний склероз в легенях - у 80,4 \%, в серці - у 76,5 \%, периваскулярна інфільтрація в легенях - у 70,7 \%, проліферація ендотелію капілярів клубочків - у $68,6 \%$, легеневих судин - у 64,7 \%, спазм судин серця - у 60,8 \%, проліферація ендотелію ниркових артеріол - у 53,0 \%, їх склероз - у 51,0 \%, проліферація ендотелію судин серця -у 49,0 \%, спазм судин легень - у 47,1\%, склероз/гіаліноз судин серця - у 35,3 \%, їх периваскулярна інфільтрація в $33,3 \%$, венозне повнокров'я - в 31,4\%, периваскулярна наявність хмарних клітин у легені - В $17,7 \%$, а в судинній стінці - у 15,7 \%.

Тільки несприятливий стан повітря із забрудненням його ксенобіотиками, але без додаткового моделювання САРЗ, не викликав появи хмарних клітин у периваскулярному просторі легень, периваскулярної інфільтрації в серце і проліферації ендотелію ниркових артеріол (рис. 1). Водночас у 3 групі тварин зміни судин легень виявлено в 40,0 \% випадків, а серця й нирок - відповідно в $33,3 \%$. Необхідно зазначити, що негативне середовище існування інтактних щурів у кожної другої особини викликало периваскулярну легеневу інфільтрацію та морфологічні ознаки скле-

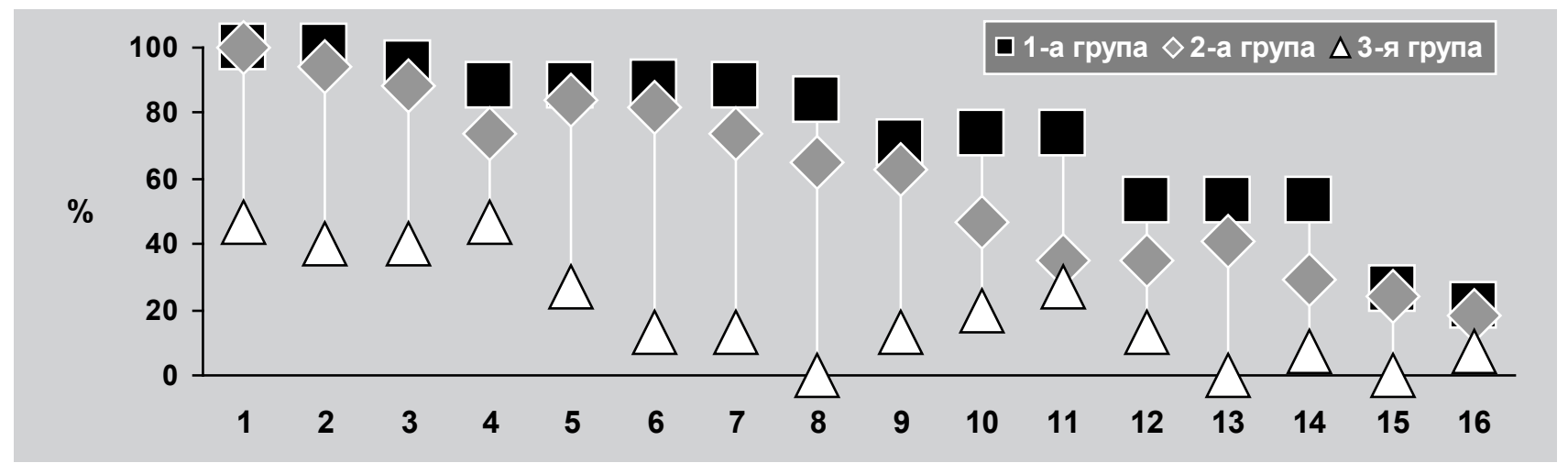

Рис. 1. Частота окремих ознак ураження судин легень, серця і нирок у обстежених тварин (\%): 1 - склероз/ гіаліноз стінки легеневих судин; 2 - периваскулярний склероз в легенях; 3 - периваскулярний склероз у серці; 4 периваскулярна інфільтрація в легенях; 5 - проліферація ендотелію капілярів клубочків; 6 - проліферація ендотелію легеневих судин; 7 - спазм судин серця, 8 - проліферація ендотелію ниркових артеріол; 9 - склероз ниркових артеріол; 10 - проліферація ендотелію судин серця; 11 - спазм судин легень; 12 - склероз/гіаліноз судин серця; 13 - периваскулярна інфільтрація судин серця; 14 - венозне повнокров'я судин серця; 15 - периваскулярна наявність хмарних клітин у легені; 16 - наявність хмарних клітин у судинній стінці легені. 
Огляди літератури, оригінальні дослідження, погляд на проблему

розу/гіалінозу стінки судин легень. Загалом негативні характеристики навколишнього повітря сприяли формуванню у тварин різноманітної судинної патології в легенях, серці й нирках, що нагадувала таку при моделі захворювання та відрізнялася лише кількісно.

Безумовно, за даними виконаного аналізу Макнемара-Фішера, негативні екологічні умови сприяли погіршенню перебігу експериментального захворювання, що можна екстраполювати на хворих людей з САРЗ. 1 група вірогідно відрізнялася від 2 частішим (у 2,1 раза) розвитком спазму судин легень, на 68 \% більшою частотою проліферації ендотелію серця і на 52 \% - ендотелію артеріол нирок. Як свідчить параметричний аналіз Пірсона, в 1 групі СПП легень прямо корелює із СПП нирок, а в 2 - СПП легень із СПП серця, що відо6ражено на рисунках 2 і 3.

Як і передбачалося, СПП судин легень, серця та нирок високодостовірно відрізнявся як у тва-

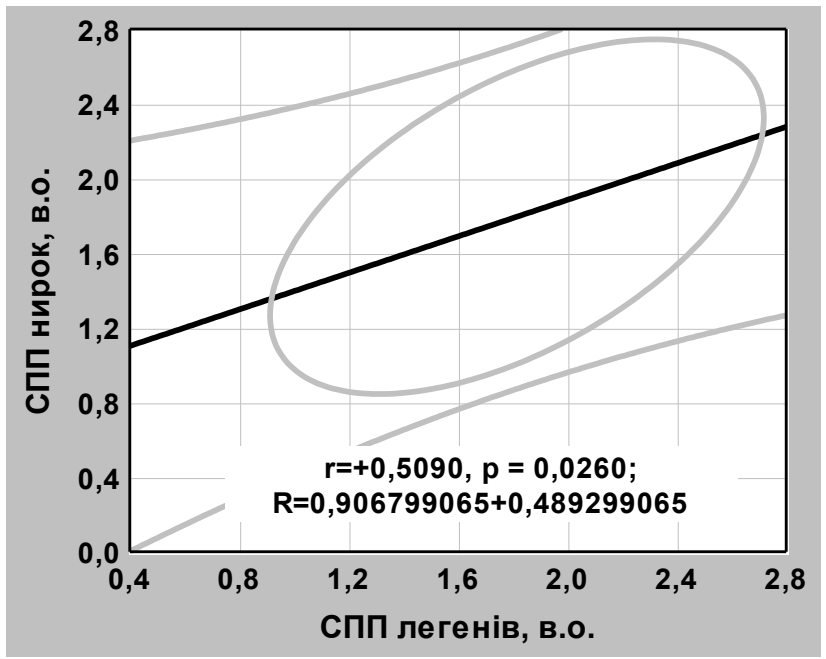

Рис. 2. Прямий кореляційно-регресійний взаємозв'язок СПП легень і нирок у тварин 1 групи.

Висновки. 1. Зміни з боку легень, серця й нирок спостерігаються у всіх тварин з експериментальним САРЗ та, відповідно, у 47 \%, 47 \% і $40 \%$ інтактних щурів, які перебували в несприятливому середовищі із забрудненим ксенобіотиками повітрям (аміак+бензол+формалін), при цьому у кожної третьої-четвертої особини розвивалося ураження судин внутрішніх органів.

2. Негативна екологічна ситуація підвищує частоту таких морфологічних ознак захворювання як проліферація ендотелію судин серця та ниркових артеріол, до того ж, існують прямі кореляційні зв'язки ступеня ангіопатії в окремих органах, що залежить від характеру моделювання патологічного процесу і доводить, що забруднен- рин 1 й 3 груп, так і у піддослідних 2 й 3 груп. При цьому СПП судин серця виявився вірогідно більшим (на $36 \%$ ) у щурів основної групи, порівняно 3 2. Тому можна стверджувати, що несприятливе за рівнем ксенобіотиків повітряне середовище $\epsilon$ чинником ризику ураження судин серця не лише у тварин з моделлю САРЗ, а й у хворих людей.

Безпосередньо з моделлю САРЗ пов'язаний вплив склерозу легеневих судин на розвиток бронхосклерозу, периваскулярної інфільтрації м'яза серця на лімфоцитарно-макрофагальну інфільтрацію строми міокарда й склерозу ниркових артеріол на ступінь нефросклерозу строми, тоді як забруднення повітря ксенобіотиками визначає залежності виразності клітинної інфільтрації альвеолярних перегородок від периваскулярної легеневої інфільтрації, розвиток гіпертрофії кардіоміоцитів від проліферації ендотелію судин серця, збільшення мезангіального матриксу нирок від проліферації ендотелію клубочкових капілярів.

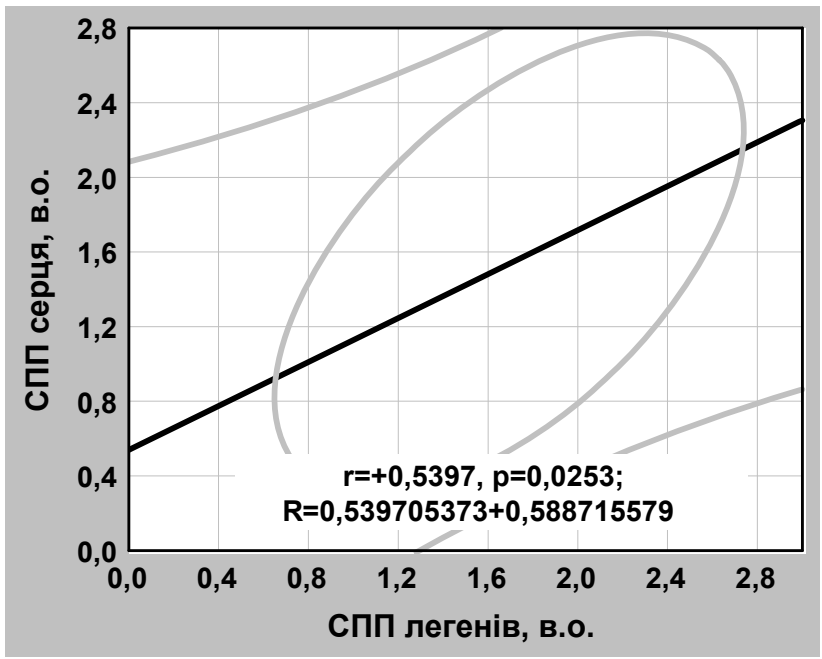

Рис. 3. Прямий кореляційно-регресійний взаємозв'язок СПП легень і серця у тварин 2 групи.

ня атмосфери є чинником ризику захворювання у людей.

3. Існують певні особливості впливу на структурні зміни судин внутрішніх органів безпосередньо моделі САРЗ та забруднення повітря ксенобіотиками.

Перспективи подальших досліджень. Подані в роботі відомості вимагають обов'язкового дослідження судин (виконання сонографії, капілярографії, біомікроскопії кон'юнктиви тощо) вже на ранніх етапах спостереження за хворими на САРЗ, які мешкають у регіонах з несприятливим складом повітря, що вдихається, для своєчасного здійснення відповідних лікувально-профілактичних заходів у контексті виявленої ангіопатії. 


\section{Огляди літератури, оригінальні дослідження, погляд на проблему \\ ЛІТЕРАТУРА}

1. Google-driven search for big data in autoimmune geoepidemiology: analysis of 394.827 patients with systemic autoimmune diseases / M. Ramos-Casals, P. Brito-Zerón, B. Kostov [et al.] // Autoimmun. Rev. - 2015. Vol. 14, № 8. - P. 670-679.

2. Outcome of patients with systemic diseases admitted to the medical intensive care unit of a tertiary referral hospital: a single-centre retrospective study / T. Heijnen, A. Wilmer, D. Blockmans, L. Henckaerts // Scand. J. Rheumatol. - 2016. - Vol. 45, № 2. - P. 146-150.

3. Dey-Rao R. Genome-wide transcriptional profiling data from chronic cutaneous lupus erythematosus (CCLE) peripheral blood / R. Dey-Rao, A. A. Sinha // Data Brief. 2014. - Vol. 11, № 2. - P. 39-41.

4. Hoffman G. S. Vasculitis: determinants of disease patterns / G. S. Hoffman, L. H. Calabrese // Nat. Rev. Rheumatol. - 2014. - Vol. 10, № 8. - P. 454-462.

5. The pathogenic role of angiogenesis in rheumatoid arthritis / H. A. Elshabrawy, Z. Chen, M. V. Volin [et al.] // Angiogenesis. - 2015. - Vol. 18, № 4. - P. 433-448.

6. Medium vessel vasculitis in systemic lupus erythematosus / A. Maldonado, J. N. Blanzari, P. Asbert [et al.] // Rev. Fac. Cien. Med. Univ. Nac. Cordoba. - 2016. - Vol. 73, № 1. - P. 50-52.

7. Clinical scenarios in chronic kidney disease: parenchymal chronic renal diseases / I. Petrucci, S. Samoni, M. Meola [et al.] // Contrib. Nephrol. - 2016. - Vol. 188 - P. 98-107.

8. Patient with rheumatoid arthritis and acute renal failure: a case report and review of literature / A. Marszałek, N. Skoczylas-Makowska, A. Kardymowicz, J. Manitius // Pol. J. Pathol. - 2010. - Vol. 61, № 4. - P. 229-233.

9. Fatal cardiac small-vessel involvement in ANCAassociated vasculitis: an autopsy case report / S. Iwasaki, A. Suzuki, T. Fujisawa [et al.] // Cardiovasc. Pathol. - 2015. - Vol. 24, № 6. - P. 408-410.

\section{REFERENCES}

1. Ramos-Casals, M., Brito-Zerón, P., Kostov, B., SisóAlmirall, A., Bosch, X., \& Buss, D. (2015). Google-driven search for big data in autoimmune geoepidemiology: analysis of 394,827 patients with systemic autoimmune diseases. Autoimmun. Rev., 14 (8), 670-679. doi: 10.1016/j. autrev.2015.03.008.

2. Heijnen, T., Wilmer, A., Blockmans, D., \& Henckaerts, L. (2016). Outcome of patients with systemic diseases admitted to the medical intensive care unit of a tertiary referral hospital: a single-centre retrospective study. Scand. J. Rheumatol. 45 (2), 146-150.

3. Dey-Rao, R., \& Sinha, A.A. (2014). Genome-wide transcriptional profiling data from chronic cutaneous lupus erythematosus (CCLE) peripheral blood. Data Brief, 11 (2), 39-41. doi: 10.1016/j.dib.2014.11.006.

4. Hoffman, G.S., Calabrese, L.H. (2014). Vasculitis: determinants of disease patterns. Nat. Rev. Rheumatol., 10 (8), 454-62. doi: 10.1038/nrrheum.2014.89.

5. Elshabrawy, H.A., Chen, Z., Volin, M.V., Ravella, S., Virupannavar, S., \& Shahrara, S. (2015). The pathogenic role of angiogenesis in rheumatoid arthritis. Angiogenesis,
10. Изменения респираторной системы при экспериментальной модели аутоиммунного заболевания на фоне лечения / О. В. Синяченко, М.В.Ермолаева, Е. Д. Егудина, А. А. Фаерман // Укр. ревматол. журн. - 2004. - Т. 18, № 4. - С. 3-6.

11. Синяченко П. О. Поражение эндокарда и клапанов сердца при экспериментальной системной красной волчанке / П. О. Синяченко, Г. А. Игнатенко, Е. А. Дядык // Вест. неотложн. восстанов. мед. - 2011. T. 12, № 1. - С. 102-105.

12. Бевзенко Т. Б. Морфологические изменения почек при экспериментальном системном васкулите // Почки. Нирки. - 2015. - Т. 13, № 3. - С. 33-36.

13. Синяченко О. В. Ревматические заболевания и экология //Укр. ревматол. журн. -2007.-Т. 30, № 4. -С. 64-68.

14. Mora G. F. Systemic sclerosis: environmental factors / G. F. Mora // J. Rheumatol. - 2009. - Vol. 36, № 11. - P. 2383-2396.

15. Identification of an association of TNFAIP3 polymorphisms with matrix metalloproteinase expression in fibroblasts in an integrative study of systemic sclerosisassociated genetic and environmental factors / P. Wei, Y. Yang, X. Guo [et al.] // Arthritis Rheumatol. - 2016. Vol. 68, № 3. - P. 749-760.

16. Interstitial Lung Disease Associated With Systemic Sclerosis and Idiopathic Pulmonary Fibrosis / L. Erica, L. Aditi Mathur, Andrew M. Tager, Carol Feghali-Bostwick // Arthritis Rheumatol. - 2014. - Vol. 66, № 8. - P. 1967-1978.

17. Barnes J. Epidemiology of systemic sclerosis: incidence, prevalence, survival, risk factors, malignancy, and environmental triggers / J. Barnes, M. D. Mayes // Curr. Opin. Rheumatol. - 2012. - Vol. 24, № 2. - P. 165-170.

18. Спосіб моделювання системного аутоімунного захворювання / Ю. І. Ніколенко, О. В. Синяченко, В. Ю. Ніколенко, М. М. Анан'єва // Пат. UA № 6G09B 23/28 від 30.10.98 р.

18 (4), 433-448. doi: 10.1007/s10456-015-9477-2.

6. Maldonado, A., Blanzari, J.N., Asbert, P., Albiero, J.A., Gobbi, C., \& Albiero, E. (2016). Medium vessel vasculitis in systemic lupus erythematosus. Rev. Fac. Cien. Med. Univ. Nac. Cordoba, 73 (1), 50-52.

7. Petrucci, I., Samoni, S., Meola, M. (2016). Clinical scenarios in chronic kidney disease: parenchymal chronic renal diseases. Contrib. Nephrol.,188, 98-107. doi:10.1159/000445472.

8. Marszałek, A., Skoczylas-Makowska, N., Kardymowicz, A., Manitius, J. (2010). Patient with rheumatoid arthritis and acute renal failure: a case report and review of literature. Pol. J. Pathol., 61 (4), 229-233.

9. Iwasaki, S., Suzuki, A., Fujisawa, T., Sato, T., Shirai, S., \& Kamigaki, M. (2015). Fatal cardiac small-vessel involvement in ANCA-associated vasculitis: an autopsy case report. Cardiovascular Pathology, 24 (6), 408-410. doi: 10.1016/j.carpath.2015.07.005

10. Synyachenko, O.V., Yermolaeva, M.V., legudyna, Ye.D., \& Faerman, A.A. (2004). Izmeneniya respiratornoy sistemy pri eksperymentalnoy modeli autoimmunno- 
Огляди літератури, оригінальні дослідження, погляд на проблему

go zabolevaniya na fone lecheniya [Changes in the respiratory system in the experimental model of an autoimmune disease against treatment]. Ukr. revmatol. zhurn. - Ukrainian, Reumatological Journal, 18 (4), 3-6 [in Ukrainian].

11. Syniachenko, P.O., Ignatenko, G.A., Dyadik, E.A. (2011). Porazhenye endokarda i klapanov serdtsa pri eksperimentalnoy sistemnoy krasnoy volchanki [Endocardial and valvular heart disease in experimental systemic lupus erythematosus]. Vest. neotlozhn. vosstanov. med. Journal of Emergency Recurrence Medicine, 12 (1), 102-105 [in Ukrainian].

12. Bevzenko, T.B. (2015) Morfologicheskie izmenenia pochek pri eksperymentalnom sistemnom vaskulite [Morphological changes in the kidneys with experimental systemic vasculitis]. Pochky - Kidneys, 13 (3), 33-36 [in Ukrainian].

13. Syniachenko, O.V. (2007) Revmaticheskie zabolevania i ekologia [Rheumatic diseases and ecology]. Ukr. revmatol. zhurn. - Ukrainian Reumatological Journal, 30 (4), 64-68 [in Ukrainian].

14. Mora, G.F. (2009) Systemic sclerosis: environmental factors. J. Rheumatol. 36 (11), 2383-2396.
15. Wei, P., Yang, Y., Guo, X., Hei, N., Lai, S., \& Assassi, S. (2016). Identification of an Association of TNFAIP3 polymorphisms with matrix metalloproteinase expression in fibroblasts in an integrative study of systemic sclerosisassociated genetic and environmental factors. Arthritis Rheumatol. 68 (3), 749-760. doi: 10.1002/art.39476.

16. Erica, L. Herzog, Aditi, M., Andrew, M. Tager, Feghali-Bostwick, \& Carol (2014). Interstitial Lung Disease Associated With Systemic Sclerosis and Idiopathic Pulmonary Fibrosis. Arthritis Rheumatol., 66 (8), 1967-1978. doi: 10.1002/art.38702

17. Barnes, J., Mayes, M.D. (2012) Epidemiology of systemic sclerosis: incidence, prevalence, survival, risk factors, malignancy, and environmental triggers. Curr. Opin. Rheumatol., 24 (2), 165-170. doi: 10.1097/ BOR.0b013e32834ff2e8.

18. Nikolenko, Iu.I., Syniachenko, O.V., Nikolenko, V.Yu., \& Ananieva M.M. Sposib modeliuvannia systemnoho autoimunnoho zakhvoriuvannia [The process of modeling systemic autoimmunity]. Pat. UA № $6 \mathrm{G} 09 \mathrm{~V} 23 / 28$ vid 30.10 .98 r.

\title{
ВЛИЯНИЕ КСЕНОБИОТИКОВ В ВОЗДУХЕ НА ТЕЧЕНИЕ АНГИОПАТИИ У КРЫС С МОДЕЛЬЮ СИСТЕМНОГО АУТОИММУННОГО РЕВМАТИЧЕСКОГО ЗАБОЛЕВАНИЯ
}

\author{
๑Е. Д. Егудина', Г. С. Такташов², В. Я. Микукст², О. В. Синяченко², В. И. Суярко² \\ ${ }^{1} Г у$ «Днепропетровская медицинская академия МОз Украины» \\ ${ }^{2}$ Донецкий национальный медицинский университет (2. Лиман)
}

PEзЮМЕ. Системные аутоиммунные ревматические заболевания (САРЗ) связаны с неблагоприятными факторами окружающей среды, которые определяют темпы прогрессирования и выживаемость больных. Загрязнение атмосферы полютантами способствует увеличению в таких регионах распространенности этих болезней.

Цель исследования - оценить влияние ксенобиотиков в воздухе на характер морфологических изменений сосудов легких, сердца и почек у животных с моделью САРЗ.

Материалы и методы. Эксперимент проведен на беспородных крысах, которых поделили на три группы: в первую вошли животные с моделью ССД, которые находились ежедневно по пять часов в неблагоприятной атмосферной среде (аммиак+бензол+формалин), вторую составили животные с моделью заболевания, содержащиеся в обычных экологических условиях, а в третью вошли интактные крысы, которых помещали в среду с высоким содержанием в воздухе ксенобиотиков, как и представителей первой группы.

Гистологические срезы тканей сердца, легких и почек окрашивали гематоксилином-эозином, альциановим синим и по ван-Гизон, ставили PAS-реакцию.

Результаты. Изменения со стороны легких, сердца и почек обнаружены у всех животных с экспериментальным САРЗ и, соответственно, в $47 \%$, 47 \% и 40 \% наблюдений интактных крыс, находящихся в неблагоприятной среде с загрязнением воздуха ксенобиотиками. Негативная экологическая ситуация повышала частоту таких морфологических признаков заболевания как пролиферация эндотелия сосудов сердца на 68 \% и почечных артериол на 52 \%, к тому же существовали прямые корреляционные связи степени ангиопатии в отдельных органах, что зависело от характера моделирования патологического процесса и доказывало факт загрязнения атмосферы как фактор риска заболевания у людей. Непосредственно с моделью САРЗ было связано влияние склероза легочных сосудов на развитие бронхосклероза, периваскулярной инфильтрации мышцы сердца, тогда как загрязнение воздуха ксенобиотиками определяло зависимость степени клеточной инфильтрации альвеолярных перегородок от периваскулярной легочной инфильтрации, развитие гипертрофии кардиомиоцитов от пролиферации эндотелия сосудов сердца, увеличение мезангиального матрикса почек от пролиферации эндотелия клубочковых капилляров. 
Огляди літератури, оригінальні дослідження, погляд на проблему

Вывод. Загрязнение атмосферы ксенобиотиками должно рассматриваться как негативный фактор в отношении развития и последующего течения САРЗ у людей, а в патогенетических его построениях ведущее значение имеет ангиопатия.

Ключевые слова: системное аутоиммунное ревматическое заболевание; эксперимент; сосуды; воздух; ксенобиотики.

\section{XENOBIOTICS INFLUENCE IN THE AIR ON THE COURSE OF ANGIOPATHY IN RATS TO MODEL SYSTEMIC AUTOIMMUNE RHEUMATIC DISEASES

\author{
@Ye. D. legudina', G. S. Taktashov², V. Ya. Mikuksts², O. V. Syniachenko², V. I. Suyarko² \\ ${ }^{1}$ Dnipropetrovsk Medical Academy \\ ${ }^{2}$ Donetsk National Medical University, Lyman
}

SUMMARY. Systemic autoimmune rheumatic diseases (SARD) associated with adverse environmental factors that determine the rate of disease progression and survival of patients. The prevalence of these diseases increases in the regions with air pollution.

The aim of the study - to evaluate the effect of xenobiotics in the air on the character of morphological changes in the lung blood vessels, heart and kidneys in animal with SARD models.

Materials and Methods. The experiment was conducted on outbred rats, which were divided into three groups: the first - rats with the SARD model underwent by five hours in unfavorable atmospheric environment daily (ammonia + benzene + formalin), the second - was composed by the animal with the disease model, but were kept in normal environmental conditions, and the third - includes intact rats, which were placed in an environment with a high content of xenobiotics in the air, as well as representatives of the first group. Histological sections of the heart tissue, lung and kidney were stained with hematoxylin-eosin, alcian blue and Van Gieson, becoming the PAS-reaction.

Results. Changes in the lungs, heart and kidneys are found in all animals with an experimental SARD respectively $47 \%, 47 \%$ and $40 \%$ of cases of intact rats in a hostile environment with xenobiotics air pollution. The negative environmental situation increased the frequency of morphological signs of the disease, as the proliferation of endothelial vessels of the heart by $68 \%$ and renal arterioles by $52 \%$, in addition, there was a direct correlation the degree of angiopathy in individual organs, which depended from the nature of the pathological process simulation and proved the fact of atmospheric pollution as human disease risk factor. Directly with SARD model was associated the impact of pulmonary vessels sclerosis on the development of bronchosklerosis, perivascular infiltration of the heart muscle, whereas xenobiotics air pollution determined the dependence of the degree of cellular infiltration of alveolar septa by perivascular pulmonary infiltration, the development of hypertrophy of cardiomyocytes from the proliferation of endothelial vessels of the heart, kidney mesangial matrix increase from the proliferation of endothelial glomerular capillaries.

Conclusion. The pollution of the atmosphere by xenobiotics should be considered as a negative factor in the development and the subsequent flow of SARD in people, and in his patogenic constructions the leading importance has angiopathy.

Key words: systemic autoimmune rheumatic disease; experiment; vessels; air; xenobiotics. 